\title{
El Diálogo Pastoril en los Siglos de Oro
}

\author{
FRANCISCO LÓPEZ ESTRADA \\ Universidad Complutense
}

\section{Limitación del asunto}

Asusta situarse ante la enorme extensión temporal y la diversidad genérica que existe en la literatura pastoril. El macrosistema pastoril abarca desde los orígenes griegos hasta el Romanticismo, y aún luego permanece en determinados casos por afinidades culturales, y en otros por la condición personal del escritor. Cernuda escribe en 1927 una Egloga, sin que sienta inhibición en su propósito de modernidad. En este caso, por fortuna para mí, el espacio temporal en el que se sitúa mi propósito limita el cometido. Pretendo relacionar al pastor con la literatura de los diálogos en el Renacimiento español del siglo XVI. Esto reducirá mi campo, pero me amenaza otro peligro en cuanto a la extensión, y es que esta época-como habrán podido reconocer los que la han estudiado- se caracteriza por un cultivo intenso de la literatura de los diálogos. Luis Andrés Murillo ${ }^{1}$ estima que entre 1525 y 1600 se escribieron un millar de diálogos. Jacqueline Ferreras ${ }^{2}$ se apoya en noventa y un libros para elaborar su estudio

1. Luis Andrós Murillo, "Bialogo y dialéctica en el siglo XV' español», Revista de la Unibersidad de Buenos : Lires, 4 (1959), p. 56.

-2. Jacqueline Ferreras, Les dialogues espagnols du XVI' siècle ou l'expression littéraire d'une nouvelle conscience, (París, Didier, 1985). 
sobre lo que representan los diálogos para establecer la expresión literaria de una conciencia nueva en la España del siglo XVI. Las cifras mencionadas indican la extensión del dominio literario en que habremos de movernos; dentro del mismo tengamos pues, en cuenta los dos factores en juego: pastores, por un lado, y diálogo por otro, y consideremos si de su acercamiento resulta una entidad literaria que sea el diálogo pastoril en el periodo en que se desarrollan este género de obras en la literatura española ${ }^{3}$.

\section{La cuestión desde los orígenes}

En cuanto a la literatura pastoril, hubo siempre en sus protagonistas, los pastores, una marcada vocación por entablar diálogos y conversar entre ellos. Como punto de partida esencial, he de referirme a una obra que serviría como molde común, dentro del cual obtendrían forma las creaciones de la literatura pastoril; me refiero a las Bucólicas de Virgilio. En su concepción general de conjunto, cada Bucólica, por sí misma o descompuesta en piezas, es una obra magistral que conocieron -y probablemente estudiaron- los que escriben diálogos en España, pues se trata de escritores cultos, con una cierta formación en Humanidades, en la que las Bucólicas de Virgilio fue una obra conocida por todos. Y resulta que el diálogo, en el sentido primario de conversación, en un procedimiento expositivo muy usado en las Bucólicas: así hay diálogo de dos pastores en las I, III, V, VIII, y IX. Y las otras son monólogos: II, IV, VI; y la X posee un germen de novelización. La III cuenta con tres personajes, y manifiesta un esbozo de teatralidad. O sea que en la pieza poética ejemplar de la literatura pastoril latina la conversación entre los pastores es un factor sustantivo, y presenta las mismas tendencias que aquí se habrán indicado que amenazan al género: que pase de diálogo estricto o a obra teatral o a relato novelístico, o que un interlocutor se imponga a los demás y lo convierta en monólogo. Detrás de las Bucólicas, en la lengua española hereda esta misma condición ejemplar y modélica la obra de Garcilaso. Un rápido recuento nos da este resultado: en la I Egloga, nombre con el que fueron conocidas las obras del mismo patrón europeas, en latín o en las lenguas vernáculas, después de la in-

3. Llubiera convenido establecer los antecedentes de este diálogo renacentista en relación con las obras análogas del siglo $\mathrm{XV}$ en especial, y con las anteriores; véase Francisco López Estrada, "Anuncios renacentistas en el Libro de los pensamientos variables", en el Homenaje al Prof. Eugenio Asensio, Madrid, Gredos, 198L, pp. $277-289$. 
troducción del poeta-relator, hablan poéticamente los dos pastores, pero Salicio no se dirige al otro pastor presente, sino a Galatea "así como presente razonando con ella le decía" (vv. 55-56), y Nemoroso se dirige a su Elisa, o sea un diálogo con el interlocutor ausente. La Egloga II tiene cuatro personajes: Albanio, Salicio, Nemoroso y Camila, y Herrera declara en sus comentarios que es "poema dramático»" Y la complejidad crece en la III, en la que el poeta es el relator del contenido pastoril, y en el curso de la exposición Tirreno y Alcino entablan un canto parejo: "cantando el uno, el otro respondiendo" (v. 304); en este punto comenta Herrera: «Denota la naturaleza del verso amebeo [...]. La ley de este verso es decir cosas mayores o contrarias que el primero" ${ }^{5}$.

Por tanto, en la tradición y en la práctica poética de la época, los pastores resultan propensos a la conversación, pero esto no significa que sean interlocutores propicios para un diálogo, tal como se requiere según la contextura literaria del género que aquí tratamos. La conversación en las églogas resbala enseguida hacia otros órdenes de expresión diferentes de los diálogos, y el crítico echa de ver la teatralidad que aparece en cuanto un poeta como Herrera adopta un talante crítico. Esto rompe los moldes habituales de la historia literaria, que sitúan a Garcilaso (y detrás de él a los autores de églogas, tan numerosos) en el cajón de la lírica. Y esta percepción teatral de la égloga fue general, pues cuando don Quijote encuentra en la Segunda Parte de su libro un grupo de doncellas y jóvenes que celebran una fiesta vestidos de pastores, estas le dicen: "Traemos estudiadas dos églogas, una del famoso poeta Garcilaso, y otra del excelentísimo Camoes [...], las cuales hasta ahora no hemos representado" (II, 58). Este deslizamiento hacia la teatralidad sería además favorecido por la figura del pastor del teatro paralelo en la época y que llega hasta Lope.

\section{Afirmación de la prosa como módulo general del diálogo renacentista}

Los pastores de los diálogos que aquí estudiaremos no se pueden expresar ni en el hexámetro de las Bucólicas, ni en la métrica latina

\footnotetext{
4. Garcilaso de la Vega y sus comentaristas, ed. Antonio Gallego Morell (Granada, Universidad, 1966), p. 482.

5. Idem, p. 570 .
} 
de su descendencia, ni tampoco en la métrica vernácula de Garcilaso, ni en otras manifestaciones poéticas como las de Castillejo. La égloga, sea latina o sea vulgar, implica una elaboración artística peculiar que sólo logra su perfección formal y retórica en el verso. Por el contratio, el género del diálogo renacentista, en sus obras más características, discurre por el cauce de una prosa que resulta adecuada para su fin como consecuencia de los recursos de una poética que apenas llegó a formularse, pero que existía por un acuerdo que se había establecido entre los autores y los lectores de estos diálogos. Y cuando alguien se salía de este acuerdo, se notaba como una estridencia que el autor pretendía justificar de algún modo. Lorenzo Suárez de Chaves publica unos Diálogos de varias cuestiones, en diálogos y metros castellanos, y en el prólogo tiene que explicar el motivo por el que los escribe en verso: «... para los que no entienden latín, o no les da contento leer en prosa, hallen en verso vulgar lo que, después de leído, les podrá traer algún fruto" ${ }^{6}$. Estos son diálogos "con fruto", y es de interés la clasificación que nos da de los lectores de diálogos: los eruditos los leen en latín, y estos pueden alcanzar las obras más perfectas de una manera directa; otros los leen en lengua vernácula, y estos son los que aquí estudiamos, y están escritos, como marca la poética implícita de estas obras, en prosa; y otros los prefieren en el verso vulgar, porque esto les da más contento que la prosa. Nuestra vía es la de la prosa, es decir la de los lectores que, aunque la obra esté en la lengua moderna, quieren esforzarse por penetrar en su contenido; y nos importan los pastores en esta función de interlocutores prosísticos.

En las primeras décadas del siglo XVI, el pastor que domina en el teatro es el rústico, y las Bucólicas de Virgilio se visten de lengua castellana por la obra y gracia poética de Juan del Encina, que las presenta a los Reyes dándoles una versión actualizada; así le dice al príncipe don Juan que quiere aplicarle parte de ellas. Esto es, que no sólo traduce el texto latino, atemporal para sus efectos, sino que busca en la historia reciente del siglo XV un paralelo aplicable al caso contado en la Bucólica. Vierte la obra «en estilo rústico, por consonar con el poeta que introduze personas pastoriles..." ${ }^{7}$. Esta rusticidad, proseguida por el teatro prelopista, asegura la pervivencia del saya-

6. Lorenzo Suárez de Chaves, Diálogos de varias cuestiones..., (Alcalá de Henares, Juan Gracián, 1577), dedicatoria preliminar al Rey.

7. Cancionero de Juan del Encina, facsímil de la edición de 1496 (Madrid, Revista de Archivos, Bibliotecas y Museos, 1928), fol. XXXII. 
gués como distintivo propio de esta interpretación pastoril (sobre todo teatral), y este sayagués sitúa la obra en un contexto español, dentro de una determinada lengua vulgar de la que el autor tira "para abajo", hacia determinada vulgaridad que acaba convirtiéndose en lengua literaria, aunque resulte paradoja.

\section{El pastor y las obras celestinescas}

Conservando estas características, el pastor se incorpora, desde luego que en medida escasa, al grupo genérico que crece detrás de la Celestina. Por la misma constitución de la Celestina, esto resulta posible, pues es obra de difícil clasificación, y en su constitución muchos la entendieron como un diálogo muy complejo por la estructura de su presentación, el número y variedad de sus personajes, el uso de la prosa y el lento discurso carente del ritmo propio de la teatralidad. Y así en la Segunda Celestina de Feliciano de Silva, debido al carácter abierto de esta clase de obras, se introduce un pastor, Filínides, que conversa con la señora Polandria y la criada Poncia, y les cuenta sus amores con la pastora Acais. A pesar de llamarse con nombre tan artístico, Filínides usa el habla villanesca en el léxico, pero desarrolla su conversación siguiendo el curso de una sintaxis ciceroniana. Ofrece unas cucharas de madera e, incitado por la señora y la criada, les comunica su caso de amor. El personaje resulta ambiguo, y Porcia emite este dictamen sobre la contradicción que comporta, tratando de resolver el desconcierto de Polandria: «Señora, no te maravilles que, como espíritu, habla en él el amor, que él es el que dice la sentencia, y la lengua pronuncia conforme a su natural las palabras groseramente». Y esto es lo que hay que superar si queremos que el pastor pueda ser un personaje que se codee sin desdoro linguístico con los protagonistas de los otros diálogos de la época.

\section{Los protagonistas de los diálogos}

Salvado esto, el pastor hubiera podido ser un protagonista de los diálogos renacentistas. Motivos no faltan para justificar esta participación. Una cuestión previa es la del título de este grupo genérico, que se habrá planteado ya antes en otras ocasiones. El término diálogo es el más general, y se sitúa a la sombra de la tradición de Platón y de Cicerón; con él se usa el de coloquio, que implica la modernidad

8. Feliciano de Silva, Segunda Comedia de Celestina, [1536], (Madrid, Colección española de libros raros o curiosos, 1874), p. 398. 
de los diálogos de Erasmo, titulados Colloquia, y vertidos a partir de 1528 como coloquios. El esfuerzo por distinguir ambos términos no llega a ningún resultado práctico. Luis Alfonso de Carballo en su Cisne de Apolo (1602) sitúa diálogos y coloquios con las formas dramáticas, y del coloquio dice que uespecie es de comedia pero no tiene más de hasta seis personas que disputan o hablan sobre alguna cosa, [...] que al fin no es más que una conversación"; y del diálogo, que "es plática entre dos, o a lo sumo tres [...] Y en este estilo se ponen y enseñan muchas y muy buenas doctrinas» ${ }^{9}$. Esto, sin embargo, no es más que un propósito, y la variedad de los diálogos, dentro de una sustancial orientación, es grande y distinta. $Y$ aún pudiéramos añadir los nombres de la tradición medieval disputa, querella, cuestión, contienda, discusión, plática, razonamiento, y las venidas por otras partes, como simposio, convite. No hay una teoría establecida con certeza, y el diálogo tiene así una fluidez formal que acusan los que han estudiado la gran variedad de los asuntos expuestos en ellos y, consiguientemente, la diversidad de interlocutores; en ellos importarán más los rasgos sociales que los identifican como pertenecientes a una clase determinada, que el desarrollo de una caracterización personal o la intromisión de relatos que inclinen hacia la ficción el conjunto de la obra. Por convenir con los asuntos y por el estilo más común a estos diálogos, muchos de sus interlocutores son «caballeros de ciudad», expresión que reúne la tradición de la literatura cortés y còrtesana con la burguesa; son hidalgos (para usar el nombre español idóneo). Junto con ellos están los profesionales que conocen un dominio determinado de la vida social, por sus medios de vida o sus aficiones: hombres de letras, juristas, médicos, farmacéuticos, gente de armas, estudiantes, etc. Son menos los religiosos y la alta nobleza, y muy pocos los pastores, que son los que aquí importa considerar.

\section{Naturaleza y diálogos}

Ocurre, sin embargo, que es muy frecuente que el lugar en donde se sitúen los diálogos sea al aire libre de los campos, jardines o huertas, que es medio habitual en el que viven los pastores, en tanto que son aspectos diversos de la naturaleza. Así quedó establecido por Cicerón; el jardín de la casa y la ocasión del ocio propician el diálogo: el tan conocido dedicado a Bruto, después del preliminar, comienza: "Cierto día que, estando ocioso en casa, yo me paseaba por mi jar-

9. Luis Alfonso de Carballo, Cisne de Apolo [1602], (Madrid, CSIC, 1958), II, p. 33. 
dín...» Un comienzo semejante a este se repite en muchos casos. Y lo mismo ocurre con el fin de los diálogos o de parte de los mismos: la caída de la tarde, que, para el pastor es tiempo de conducir las ovejas al redil o a la aldea, para los interlocutores marca la ocasión de poner fin a la conversación aplazando para otro día seguir conversando. Existe, pues, un cierto paralelismo en la disposición del tiempo en las églogas y en los diálogos. Es cierto que la sucesión temporal marcada, que podría precisarse aún más, pues las horas de la siesta, bajo la sombra de los árboles, es propicia para la conversación, procede del ritmo del tiempo más perceptible para el hombre, pero es conveniente señalar que en ambos casos se trata de una percepción temporal de índole literaria, diferente de otros géneros, por ejemplo, el de la novela; y en esta diferencia coinciden églogas y diálogos en bastantes casos.

\section{El pastor no es un buen interlocutor}

Para tener conciencia del beneficio que la naturaleza representa para el hombre, parece que la gente del campo es la mejor dispuesta. Sin embargo, ocurre que los pastores se sienten integrados de tal manera en la naturaleza, que, aunque parezca paradoja, son naturales por naturaleza e historia y por la condición social de su trabajo. Y esto era una creencia general en los Siglos de Oro, que procedía de la Antigüedad. Lo prueba, como ejemplo, lo que Juan del Encina, basándose en Donato, escribe en el prólogo a los Reyes Católicos de las $B u^{-}$ cólicas: "...Siguiendo el orden de los mortales [en cabeza van los pastores] cuyo exercicio primera mente fue guardar ganados, manteniéndose de frutas silvestres; y después siguióse la agricultura; y andando más el tiempo, nacieron batallas» ${ }^{10}$. Según esta concepción, el oficio pastoril fue el primero y el que quedaba más cerca de la naturaleza original; la historia viene después con la agricultura y las guerras, ajenas al pastor. Viven lo mismo en cualquier lugar; resultan utópicos y acrónicos por naturaleza, mientras que los protagonistas de los diálogos, por el contrario, viven en una circunstancia histórica, que es la materia preferida en este género.

Por eso el pastor resulta un personaje coartado paradójicamente por su integración en la naturaleza, dentro de la cual vive en una entrega total, mientras que los protagonistas de los diálogos por lo $\mathrm{co}^{-}$ mún viven en una circunstancia acuciante, frente a la cual adoptan

10. Cancionero de Juan del Encina, ed. cit., p. XXXI. 
una posición intelectual, y como resultado de ella entablan estos diálogos en los que pretenden enseñar a los demás su experiencia o la ciencia adquirida, y por eso conversan para efectuar contrastes o cambiar pareceres. Si de enseñar se trata, tiene que ser posible la relación maestro-discípulo; si de conversar, que sean iguales y radicados en el centro de las cuestiones que se debaten, con toda la problemática de opiniones diferentes y aun contrarias. ¿Qué puede hacer el monocorde pastor entre los interlocutores de diálogos en los Siglos de Oro? Para enseñar, le pesa al pastor la rusticidad que procede de la cercana tradición literaria y de la observación de la vida real. Si se trata de conversar entre iguales ¿qué puede aportar el diálogo pastoril a este signo de información, renovación espiritual, contribución a un mejor conocimiento del hombre y de sus actividades? Y si de dialogar con otros, es difícil el entendimiento, si antes no se le levanta convenientemente en la consideración de los demás.

\section{Antonio de Torquemada, autor de diálogos}

Sólo un autor realizó una obra que nos ofrece un apunte de respuesta a estas preguntas: Antonio de Torquemada, (hacia 1510-antes de 1570$)^{11}$. Poco sabemos de él: Bataillon ${ }^{12}$ lo considera «humanista de Astorga", siguiendo a Elsdon; fue estudiante en Salamanca (presumo que de leyes), anduvo por Italia, y allí leyó muchos libros de los que aprendería procedimientos y materias que le valdrían para la escritura de sus obras; y se deduce que no se trata de un religioso, sino que estuvo casado, pues sus hijos piden el privilegio de las Flores curiosas en 1570. Obtuvo el cargo de secretario de don Alfonso Pimentel, conde de Benavente, hijo del gran favorito de Carlos V Alonso de Pimentel, que llegó a formar una gran biblioteca, como testimonia Luis de Pinedo, que dice que «... aunque no es hombre sabio ni leído, ha dado, sólo por curiosidad, en hacer librería, y no ha oído decir del

11. Una recopilación de datos sobre este autor se encuentra en Leonardo Romero Tovar, "Antonio de Torquemada, el humanista vulgar de los Coloquios satíricos», en los Estudios sobre el Siglo de Oro. Homenaje al profesor Francisco Ynduráin, (Madrid, Editora Nacional, 1984), pp. 393-409. La edición crítica de estos Coloquios y su estudio detenido se encuentran en la tesis doctoral de Lina Rodríguez Cacho, Los «Coloquios satíricos de Antonio de Torquemada. Edición y estudio, leída en la Universidad Autónoma de Madrid en 1988.

12. Marcel Bataillon, Erasmo y España, (México, Fondo de Cultura Económica, $1966^{2}$ ), p. 650 . 
libro nuevo cuando le merca, y le pone en su libreria» ${ }^{13}$. De esta biblioteca sacó el abundante material de curiosidades de que se vale nuestro autor, quien dedica los Coloquios satíricos al hijo de su señor, Alonso, de siete años de edad y en el privilegio de la obra se llama "criado del Conde de Benavente». Es decir que es un escritor en funciones de secretario, pero no a la manera ligera de Lope de Vega, sino con toda la servidumbre del oficio, como lo corrobora el que haya escrito (que no publicado) un Manual de escribientes ${ }^{14}$, acabado en 1552, en donde aconseja sobre la labor profesional del escribiente de un señor. $Y$ también es autor de un libro de curiosidades titulado Jardin de flores curiosas ${ }^{15}$. Estas tres obras tan dispares tiene un rasgo común: las tres son diálogos desde el punto de vista formal, y esto es un indicio de la amplitud temática de este grupo literario. Y hay que añadir a su obra un libro de caballerías Don Olivante de Laura, que, anónimo, llegó a la impresión, y que descompuso al cura en el escrutinio de la librería de don Quijote, y lo llamó "disparatado y arrogante" (I,6). Escritor difícil de enjuiciar, los Coloquios satíricos son la obra que aquí importa; tuvieron poca fortuna pues sólo se publicaron en Mondoñedo (1553) y en Bilbao (1584) ${ }^{16}$. Bataillon consideraba la obra «uno de los más simpáticos productos del erasmismo español ${ }^{17}$. Y, sin embargo, el tratamiento que da a la figura del pastor es contraria a la que Erasmo hace en sus Coloquios, en los que, como he expuesto en un estudio sobre este autor ${ }^{18}$, apenas se vale de los numerosos recursos de la literatura pastoril.

\section{El Coloquio satírico III}

Torquemada introduce al pastor como personaje principal del

13. Lo cito a través de Maxime Chevalier, Lectura y lectores en la España del siglo XVI y XVII, (Madrid, Turner, 1973), p. 43.

14. Tratado llamado Manual de escribientes [1552], (Madrid, Real Academia Española, 1970, ed. María Josefa Canellada y Alonso Zamora Vicente).

15. ISalamanca: J.B. de Terranova, 1570, y siete ediciones más, con traducciones al francés, italiano e inglés], (Madrid, Castalia, 1982), ed. Giovanni Allegra, quien tiene otros estudios sobre el autor.

16. Marcelino Menéndez Pelayo publicó la ed. de 1553 en los textos de su obra Origenes de la novela (Madrid, Rivadeneyra, 1907 y 1931) en la "Nueva Biblioteca de Autores Españoles». Citaré las referencias en el interior del artículo indicando la página y columna según la ed. 1931.

17. Erasmo y España, ed. cit., p. 651.

18. Francisco López Estrada, "Erasmo y los libros de pastores», en El Erasmismo en España (Santander, Biblioteca Menéndez Pelayo, 1986), pp. 457-478. 
Coloquio III, de los seis primeros que forman el bloque compacto de la obra; y son satíricos porque con ellos "se reprehenden algunos vicios» (586a): El Coloquio III propiamente no reprehende ningún vicio, sino que resulta provechoso "para que las gentes no vivan descontentas con su pobreza, no pongan la felicidad y bienaventuranza en tener grandes riquezas y gozar de grandes estados" $(615, b)$. La declaración inicial no se corresponde del todo con el contenido, porque más que elogiar la pobreza, lo que hace es acentuar las características de un pastor que no existe en la realidad social, y poco convencidos han de quedar los pobres de su defensa. En el Coloquio III acontece un encuentro entre dos caballeros que viven en la ciudad y un pastor que habita en la soledad de los campos. Florián y Leandro se han perdido en el bosque, y dan con la majada de Amintas. El nombre de Amintas procede de las Bucólicas; no es Gil, Mingo ni Pascual. Su habla no es rústica, sino una prosa elaborada, como propia de la conversación que poco a poco va levantando el vuelo literario; lejos queda el sayagués, y el habla de este pastor Amintas es la misma que la de los caballeros, sus interlocutores. Hemos sobrepasado la desigualdad lingüística, y se ha impuesto una lengua eficiente y discreta. El pastor, sin embargo, reconoce su condición humilde, y ofrece a los caballeros «la miseria en que vivimos los pastores» (616.a), pero en el curso del diálogo esta miseria se convierte en riqueza espiritual, gracias a la habilidad discursiva de Amintas. Sin embargo, del diálogo nadie sale convencido del contraste que se establece entre la vida ciudadana y la pastoril. Como dice Leandro: «Dios [...] quiere que las gentes tengan pareceres diferentes y diversos" (629.a), y concluye que "si [tú, Amintas] estás contento con la vida pastoril [...], yerro sería que la dejases, y nosotros, pues lo estamos con la que tenemos, también la seguiremos» (629.a). El coloquio pudiera haber sido un enfrentamiento entre corte o ciudad y aldea, pero en él sólo oímos las razones ponderadas del pastor. Y lo más importante que dice es el elogio de la naturaleza como posible marco social de la vida humana. Amintas pretende demostrar que las cosas naturales "tienen mayor bondad y [...] son más perfectas» (618.b), y esta bondad y perfección recae en los que viven cerca de ella, y que la vida pastoril es la más allegada a la naturaleza. La ocupación pastoril fue el primer oficio de los hombres (619.a), y los pastores participaron de la cercanía del $\mathrm{Pa}$ raíso; por el lado de los gentiles la suya fue «la edad primera y dorada» (619.a), y luego pastores fueron los que recibieron la primera noticia del nacimiento de Cristo (620.b); el ocio de la vida pastoril le permite admirar la hermosura de la Naturaleza y pasar de ella «a 
otras contemplaciones -dice- que me levantan los pensamientos a mayores cosas que las de este mundo" (623.a). Este conocimiento no sólo es intuitivo, sino asegurado en los libros, pues Amintas gusta de las lecturas. Creo que en esto el autor, Torquemada, traspasa al personaje literario su afán desmedido por leer, saciado en lá biblioteca de la casa de los Pimentel. De ahí la dimensión utópica de Amintas, que explica lo que pudieron ser los secretos deseos del autor, y así Amintas dice a los caballeros, sus interlocutores, que «los pastores pueden leer cosas que los ciudadanos, impedidos en sus tratos y conversaciones, a veces no hacen" (618.a). Con razón el caballero Leandro le dice: "Según eso, hermano Amintas, más amigo eres de la vida contemplativa que no de la activa..." (623.b). ¡Estamos declaradamente en el dominio de la Teología! Y con razón le dice el caballero: «... para hacer lo que tú dices, [...] lo mejor sería ser flaire». Pero Amintas (piénsese que Torquemada), dándose cuenta de que ha ido un poco lejos en el razonamiento, se apresura a contestar que: «... es más perfecta vida la de los flaires». Pero vuelve a la alabanza de la vida pastoril, y nos sorprende con un destello de modernidad, como se vio en otros diálogos renacentistas, al elogiar la libertad diciendo que «Si queremos gozar juntamente con la libertad del mundo, buena es la vida de los pastores" (623.b). Libertad del mundo que es compatible con el negocio de ía salvación, propio del cristiano: "y no es por fuerza que se han de salvar todos los flaires ni condenarse los que no lo son» (623.b). Y esto no lo impide el hecho de que los pastores por su trabajo apenas tengan ocasión de ir a misa ni de confesar y oigan pocos sermones. Una nota importante de Amintas es que aparece como un solitario; no habla del amor, que es la más fuerte relación humana y que más conversación requiere. Ni tampoco tiene amigos, como ha notado con acierto Jacqueline Ferreras ${ }^{19}$. El paralelo con los ermitaños, los solitarios de la Iglesia, se enuncia (624.a), especialmente porque hay en esta soledad, "por otras muchas vias, aparejo para la salvación" (624.a).

La resonancia de Erasmo es clara en cuanto al tema, y se ha llegado a su exposición de una manera ordenada, con sólo seguir el mismo curso del pensamiento. El diálogo establece un cauce expositivo en el que la razón domina por sí misma, sin que haya que citar autoridades, ni aun la de Erasmo, que pudiera ser sospechosa, y Torquemada pretende discurrir por la recta ortodoxia. El pastor define así su

19. Jacqueline Savoye de Ferreras, «El mito del pastor», Cuadernos hispanoamericanos, 308 (Febrero, 1976), p. 36. 
cometido: "A mí me parece que lo que nosotros los pastores hacemos es usar de la razón» (624.a). Y por eso el caballero Leandro dice: «...te has mostrado tan filósofo, que yo no sé qué responderte" (628.a). No hay, pues, ocasión para el diálogo verdadero; el planteamiento ha sido unilateral, aunque los interlocutores han asegurado que la diversidad es propia del hombre, un reconocimiento del humanismo; Amintas dice: "Cuántas cabezas hay, tántos son los pareceres y juicios diferentes" (617.b), lo que luego corroboraría uno de los caballeros, como antes indiqué, según es propio de la entidad constitucional del diálogo renacentista.

En esta variedad es indudable que resulta asombroso encontrar un pastor filósofo, cultivador de la razón. Es otra vía que la de la égloga; la percepción del ritmo universal, cercana a lo mágico en Virgilio, que desarrolla con profusión el tema amoroso en los poetas de las églogas, expresado en versos aparentemente humildes pero de intensa contextura artística, se cambió por el curso dialéctico de la prosa, en el uso abundante en los diálogos.

\section{El pastor del Coloquio III y el noble Selanio, coincidentes}

Pero ocurre que la defensa que el solitario Amintas hizo de la naturaleza no vale para caracterizar a este pastor como intérprete de la concepción de la vida pastoril, pues encontramos una defensa semejante en el caso de un diálogo en el que el interlocutor es un noble; esto pasa en el caso del Diálogo de Cillenia y Selanio, manuscrito de la Biblioteca Colombina de Sevilla ${ }^{20}$. Selanio es un noble cortesano, que llegó e hizo suyo lo que los interlocutores de las pláticas de Castiglione, a su imagen y semejanza, aunque en un ámbito más modesto; y siguiendo estos precedentes expone ante Cillenia las causas que le llevan a "estimar la vida del campo y solitaria" (f.5). Y, lo mismo que Amintas, Selanio se lanza a la exposición de sus "razones" (fol.5), como dice con esta precisa palabra; y estas son paralelas: el desprecio de la vida cortesana en Selanio o ciudadana en Amintas; la viva percepción de la naturaleza, ennoblecedora del espíritu y del cuerpo; la libertad de la vida pastoril y su alegría. Por eso el cortesano Selanio pide a Dios vivir entre «la rústica gente» (fol.13). La justificación es larga, y él sólo es el que habla. Cillenia, la dama, no queda convencida, y cita a su noble amigo para otro día en que piensa rebatir sus

20. Véase Francisco López Estrada, «Estudio del Diálogo de Cillana y Selanio», R.F.E. (1974-1975) pp. 159-194. 
razones. Lo que dicen Amintas y Selanio es lo mismo, bien que sea el uno pastor y el otro noble; y pretenden ambos vivir como "cristianos filósofos", dados a la "moral filosofía» (fol.10). Y, lo mismo que Amintas, reconoce que lo suyo es una opinión, y que la dama no la comparta, y le dice que: por ser "opiniones y muy varias, podéis seguir la que más os agradare» (fol.5), pues no son leyes de Dios ni del Rey.

Vemos, pues, que el pastor de Torquemada es un soporte intercambiable con el noble Silenio; ambos son extraordinarios, fuera de lo común, pero el género del diálogo les da voz como interlocutores y así pueden exponer sus puntos de vista que son concurrentes, siendo ellos distintos.

\section{El vehemente rústico del diálogo de Pedro de Navarra}

$\mathrm{Y}$ si encontramos un pastor, filósofo moral, que coincide en su apreciación social de la naturaleza con el caballero Selanio, también puede ocurrir, que manteniendo la misma rectitud moral de Amintas, otro pastor se enfrente con el noble cortesano. Así el pastor vale también para recoger el sentido cristiano de una manera radical, poniendo en el hombre del campo la virtud, al mismo tiempo que se reconoce la dureza de su vida, con una acritud que hoy nos parece una denuncia social. Esto ocurre en los Diálogos de la diferencia que hay de la vida rústica a la noble, de Pedro de Navarra $(1567)^{21}$, autor de garantía social y ortodoxa, pues aparece como hijo natural del rey de Navarra, benedictino y obispo de Comenge, y legado en Trento. En estos diálogos aparece declarado lo que antes comenté: «Noble: -¿Quién enseñó a tu padre Teología siendo rústico que araba la tierra?. Rústico:-La humildad, que es madre de la sabiduría...» En un paréntesis doctrinal escribe esto: «El hábito no salvará al fraile, si le faltan las obras» ${ }^{22}$. Y en relación con la honra, es tajante: «Noble: ¿Pues a quién llamas más honrado? Rústico: Al más justo y virtuoso" ${ }^{23}$. Pedro de Navarra no precisa que sea pastor, sino que lo llama rústico, y la suya es una vida rústica, pero el paralelo

21. Véase Pedro de Navarra, «Estudio del Diálogo de la differencia que ay de la vida rús tica a la noble... en el libro [Diálogos] (Zaragoza, Juan Millán, 1567), diálogo I, fol. 21 vuelto. El ejemplar de la Biblioteca Nacional de Madrid que consulté (R-15644) está falto de la hoja primera. Son cuatro diálogos entre el noble y el rústi $; \mathrm{B}$, en los folios 20 a 38 vuelto.

22. Idem, II, fol. 29.

23. Idem, III, fol. 30 vuelto. 
con el Coloquio III de Torquemada es evidente. Y sobre todo en los diálogos no se habla de amor, sino sólo de virtud y moral, y se diseña una vida cristiana perfecta, al menos en contraste con la de la corte; por eso el rústico es también el interlocutor más activo, y aun agresivo.

\section{El Coloquio VII de Torquemada}

Pero volvamos a Torquemada, que nos ha de deparar una sorpresa, pues junto a los Coloquios satíricos, con unidad de intención y estilo, él añade otro más. En efecto, el privilegio de impresión de la obra se pide para unos coloquios satíricos con un "colloquio pastoril al cabo" (585.a). Avalle-Arce ${ }^{24}$ ha puesto un gran empeño en demostrar la unidad del libro, pero su punto de vista es el de un crítico actual que busca las relaciones posibles para una interpretación armónica de un conjunto que efectivamente existe en cuanto a la materia del contenido, y más aún si consideramos el trasfondo ideológico común. Pero en la superficie literaria, para el autor, Torquemada, y para el público que primero leyó la obra, existía una marcada diferencia, pues él lo tituló específicamente «colloquio pastoril" (663.a), y tiene un prólogo independiente de Torquemada, sólo para este coloquio, en el que, en oposición a los coloquios "de veras" (los satíricos), llama al final a este otro coloquio "de burlas", término con el que no hay que entender que sea obra de risas, sino que el propósito de "sacar buenos exemplos y doctrina" (586.a), propio de los primeros, se atenúa, y el autor declara haberlo escrito para "entender por él el fin que se sigue en los amores que se siguen con vanidad, y cuán poca firmeza se suelen hallar en ellos» (663.a). El diálogo pastoril es como «fruta de postre» (662.a) como él mismo dice; esto significa que, en una gradación posible, el coloquio pastoril se halla en un lugar secundario. $Y$ confirma este orden la autoridad de Virgilio que «con los libros de la Eneida [...] no le pareció mal poner las Bucólicas, que tratan cosas de amores...» (663.b). La sombra de las Bucólicas se alarga hasta penetrar en estos los diálogos en prosa, pero el logro no le debió parecer positivo. Todos los personajes del Coloquio VII son pastores (Torcato y sus amigos Filonio y Grisaldo, y ella Belisia), y el cambio de pareceres no es el sustento de la obra; cierto que Torcato habla en defensa del amor, y Fi-

24. Juan Bautista Avalle-Arce, La novela pastoril española (Madrid, Istmo., 1974), pp. $49-54$ 
lonio y Grisaldo, en contra, pero esto no ocurre en el curso ordenado de una discusión, sino al hilo del caso que está contando Torcato sobre sus desafortunados amores con Belisia. La forma dialogística en este caso lleva implícita la relación de un caso de amor desde el punto de vista de uno de los implicados. Es más un monólogo entrecortado por las observaciones y consejos de los amigos. Torcato amó a Belisia poniendo por medio la pantalla de un fingido servicio a Aurelia; todo fue bien hasta que la trashumancia de los rebaños alejó a Torcato, y Belisia olvidó el amor. La queja del pastor es por la conducta de ella; sus amigos, que quieren consolarlo, lo achacan a la condición femenina. Sin embargo Belisia, en una carta, señala una causa universal: "... como las cosas no pueden permanecer siempre en su ser, antes se truecan y mudan cada hora, no te maravillarás con mucha razón de ver que en mí haya habido esta mudanza" (686.a). La cuestión de que la mujer deje de amar al hombre que quiso es un asunto que es común en la literatura de los antiguos y modernos; es un tema general y reiterado, pero aquí la pastora ofrece un motivo que, en último término, procede de esta exaltación de la naturaleza; la fórmula general proviene de un verso que hizo fortuna en España: "che per tal variar natura è bella", que, a su vez, no es más que una expresión troquelada de un tópico procedente de Serafino dell'Aquila (Aquilano), abundantemente representado en la lírica sobre todo, y que Cervantes incorpora a un soneto de Damón en el libro V de la Galatea ${ }^{25}$. También encontramos el mismo enunciado en prosa en el diálogo del sevillano Rodrigo Caro Días geniales o lúdricos, obra ya tardía $(1626)^{26}$.

La justificación de Belisia responde a esta idea común; lo que hace es arrimar el ascua a su sardina: si el mundo es vario y está en cambio, ¿por qué no pudo ella hacerlo? Son pastoras que se amparan en filosofías, lo mismo que las damas nobles. El género del diálogo sirve para ilustrar la variedad humana. Pero en este caso Belisia no es uno de los interlocutores y, por tanto, no puede defender su punto de vista; sabemos esto por una carta, y allí, en la conversación del Co-

25. Cervantes, La Galatea, (Madrid, Espasa-Calpe, 1987), p. 348.

26. En este caso es un diálogo instructivo: Rodrigo Caro, Días geniales o lúdricos, (Madrid, Espasa-Calpe, 1978), ed. Jean-Pierre Etienvre, II, p. 169. El texto en cuestión dice, por boca de don Fernando: "No todos los ingenios se inclinan de una manera; $y$ como la naturaleza en sus obras exteriores es varia para su mayor grandeza y hermosura, así ni más ni menos en el mundo menor, que es el hombre, se halla esta hermosa diversidad» II, p. 169. 
loquio, sólo aparecen Filonio y Grisaldo, los amigos que pretenden consolar a Torcato: y este es el que impone su voz haciendo un relato apasionado de su caso. El marco estricto del diálogo, tal como se encuentra en las formas ortodoxas de la época, se sobrepasa en este diálogo pastoril por el peculiar carácter de la comunicación, y se usan otras formas literarias, que se añaden en su curso: cartas y "exclamaciones" (esto es, alegatos discursivos) contra fortuna, muerte, tiempo y Belisia, y también poesías. Torquemada tiene conciencia de que su Coloquio pastoril es una obra compleja, pues avisa que su curso "va partido en tres partes: la primera es el proceso de los amores. La segunda es un sueño. En la tercera se trata de la causa que pudo haber para lo que Belisia con Torcato hizo" (663.b). Y esto es impropio de la poética del diálogo, que requiere la continuidad expositiva por parte de los interlocutores, sin estos excesos que se permite Torcato, que, por su reiteración y amplitud, apartan la obra de la disciplina que este género de obras ha ido constituyendo. Falta la calma que es propia de los interlocutores de los diálogos, y que es la disposición mental más adecuada para enfrentarse con las cuestiones que se examinan, la limitación que se imponen los que dialogan; y todo esto es ajeno al desenfreno pasional con que Torcato evoca sus amores. Es sintomático que Alejo Vanegas del Busto, un ingenio en cierto modo parejo a Torquemada, autor de una buena obra ascética, Agonía del tránsito de la muerte (Toledo, 1538), censor de la obra, diga de este Coloquio pastoril: "... el estilo sabe no solamente de pastores, más aun de muy leídos ciudadanos, en el que, aunque hay algunos avisos contra el amor [...], hay muchas celadas que enseñan a amar a los ignorantes" (585.a). Venegas se muestra contrario a los libros de ficción ${ }^{27}$, y por eso escribe esta advertencia, pues se da cuenta de que, amparándose en la moralidad que reconoce para los Coloquios satíricos, entra subrepticiamente el relato de un caso de amores, un contenido de ficción cuya expresión realiza el mismo protagonista, pastor pero conocedor de las relaciones amorosas cortesanas, y demasiado bien hablado en prosa y en verso.

En el Coloquio pastoril hay una discordancia fundamental; por una parte con él penetra en este género, como de contrabando, la ficción amorosa, impropia de los diálogos de esta naturaleza. Y, por otro lado, los pastores Filonio y Grisaldo, en una parte de su intervención,

27. Sobre todo, en el prólogo al lector que antecede a las Obras de Francisco Cervantes de Salazar, glosas y moralizaciones de otras obras (Alcalá, Juan de Brócar, 1546). 
hacen que la obra retroceda hacia la modalidad rústica, que no era válida, como dijimos, para el género. En efecto Filonio y Grisaldo, a pesar de sus pomposos nombres, se comportan como rústicos cuando interrumpen el apasionado alegato amoroso de su amigo para comer algún bocado, pues dice Filonio que lo necesita porque "no me sustento de amores, en la manera que Torcato lo hace» (682.a), y dan lugar a un intermedio pastoril paralelo al que representan sobre las tablas los pastores rústicos. Venegas notó en su censura la contradicción: suena a mentira (que es pecado moral y artístico) que un pastor hable como un caballero de ciudad, al igual que tendría que parecerlo que un noble quisiera irse al campo. Torcato lo pone de manifiesto en el proceso de sus amores con Belisia: así en el fingimiento del servicio a otra mujer que oculta como pantalla el verdadero amor del pastor, herencia del amor cortés. Y también en el desarrollo del caso amoroso, atenido al curso de la sucesión de los sentidos. En un principio, Torcato es un pastor libre, como el Amintas del Coloquio III, y así recuerda: "todo lo que miraba, me causaba alegría, con todo lo que veía me regocijaba..." (668.a), "gozando de aquella libertad..." (668.b). Pero el proceso amoroso comienza por la vista: «dándole a entender, con mirarla todas las veces que podía, lo que era vedado a mi lengua» (669.a); luego desea conversación: «Y todo mi deseo y cuidado no era otro sino poder hablar a la mi Belisia» (669.a); ya entablada la conversación, sigue el tocar: «...tomando mis groseras manos con las suyas, delicadas y hermosas, me las apretó con ellas» (676.a); y besar "...al fin, vencido de mi deseo, junté mi boca con la de mi Belisia (676.a); y abrazar: "y abrazando y besando a la mi Belisia» (676.b). Belisia lo autoriza a verla de noche para "gozar aquellos favores que yo, sin dañar del todo a mi honestidad y bondad, pudiera darte" (678.a). La enunciación de este peligroso límite no conviene con la rudeza de un pastor, sino que procede de la poesía provenzal e italiana, y se filtra hasta las normas del cortesano, que impone moderación al empuje de la carne. Torcato describe así su comportamiento: «... pasamos toda aquella noche, estando yo siempre abrazado con la mi Belisia, y las más veces la una boca con la otra, gozando della y de sus hermosas manos, sin que yo otra cosa intentase...» (679.a). ¡Razón tenía Venegas en su censura! Por de pronto, este Coloquio es impropio para Alonsito Pimentel, mozuelo de siete años, que vive en el rigor del condado de Benavente y al que se dedica la obra. Estamos desviando el diálogo para otros fines que los dialécticos o de enseñanza; Torcato se excede en hablar sobre su caso personal, y los otros no dialogan con él, sino que lo consuelan con argumentos propios de la. 
misoginia literaria, que Torcato rebate con los de la alabanza y defensa de las mujeres, aún siendo él una víctima del amor; y conste que en la amonestación del Tiempo, este le dice que él tuvo la culpa, pues no aprovechó la ocasión: "de lo cual no quesiste gozar, antes con tu flojedad temerosa perdiste los cabellos que en tu mano a mi intercesión tenías” (696.a). ¡Pobre Torcato, al que echa el Tiempo en cara su miramiento con la amada!

\section{Incompetencia del pastor como interlocutor del diálogo renacentista}

Este orden del diálogo pastoril, ya tenido por el propio autor como diferente de los satíricos, apenas arraigó en la literatura española. Cierto que queda el disfraz pastoril para quien quiera usarlo en prosa; y así en el diálogo titulado Nueva filosofía de la naturaleza del hombre (1587), puesto a nombre de Oliva Sabuco, los interlocutores son tres «pastores filósofos en vida solitaria, nombrados Antonio, Veronio y Rodonio", pero no hay más que esta mención inicial, amparada por el consabido comienzo bucólico, en cuanto a su sentido pastoril. La descripción de un lugar bucólico (aún en la forma ciudadana de jardín) como marco del diálogo es un elemento común a muchos diálogos de diversa índole, que sólo denota el aprecio general por la naturaleza, y no está en relación con la condición de los interlocutores. Esto refleja el aprecio por el campo que sienten las gentes cultas y nobles. A la consideración filosófica de la naturaleza y su proyección religiosa, le pasa otro tanto. Cierto que los pastores y los labradores (como se dice en el Diálogo de la dignidad del hombre de Pérez de Oliva $)^{28}$ son los que están en mejores condiciones para percibir estos efectos, pero esto ocurre en tanto que se les asignan estas condiciones en el contexto de la compleja tradición literaria europea. $Y$ además hallamos que el pastor (pues dejamos de lado sus diferencias con el labrador) es un interlocutor poco adecuado para un diálogo como los aquí se tratan. La humildad que le asigna la poética, en su estilo y materias que le convienen, le impide ser maestro, y cuando lo es, como en el Coloquio III, le hacen poco caso; la soledad del oficio le inclina a la introspección más que a la conversación; y cuando conversa, prefiere los asuntos de su entorno y sobre todo, cuando se trata de un diálogo pastoril, todo lo que trate de los amores propios o ajenos.

28. Fernán Pérez de Oliva, Diálogo de la dignidad del hombre, (Madrid, Editora Nacional, 1982), ed. María Luisa Cerrón Puga, pp. 110-111 y otras. 


\section{El diálogo pastoril hacia el libro de pastores: triunfo de la novelización}

Y a través del amor, damos con una característica negativa que es común a los diálogos, y que nos importa mucho; con razón destaca Ferreras que de los noventa y un diálogos examinados en su estudio, el más amplio de la literatura española, sólo cinco de ellos tienen a alguna mujer entre los interlocutores, y esto ocurre en casos tan imprescindibles como es el de los Coloquios matrimoniales de Pedro de Luján (1550). La literatura pastoril va requiriendo una mayor participación femenina; y ese fue el gran acierto de Jorge de Montemayor cuando estableció, en el cauce del relato pastoril en prosa y verso (mezcla tan incómoda para los teóricos), el desarrollo del grupo genérico que se llamó libros de pastores. En estos relatos de pastores, las mujeres tuvieron ocasión de obtener un índice elevado de presencia y actuación. No sólo eran ellos los que intervenían, sino unos y otras en una contribución semejante. La perspectiva de la consideración del hecho amoroso aumenta, y la diversidad de los casos crece. Esto resulta ser precisamente un testimonio de la variedad humana, aplicada al caso del amor. $Y$ en el curso de estos libros sí que se conversa de una manera amplia, pero no con la disciplina que requieren los diálogos, sino de una manera personal, cada personaje dispuesto a explicar su propio caso de amor, diferente de cualquier otro, y también dispuesto a oír la relación del otro pastor, por cuanto esto importa para formar la trama argumental del libro pastoril.

Pero ocurre que el grupo de los libros de pastores no recoge todas las partes constitutivas del posible diálogo pastoril (ejemplificado sólo por el Coloquio pastoril de Torquemada): se desprende de algunas y atenúan otras. Así ocurre con los elementos rústicos mencionados, aunque se reconozca una categoría de pastores rústicos. Tampoco las manifestaciones físicas del amor serán tan declaradas como las que estableció Torquemada en su coloquio pastoril; el platonismo impone su máscara asegurando una honestidad inflexible, válida como pasaporte que permite la entrada de una ficción amorosa, de orden espiritual y profana. El primer libro de Montemayor fue precisamente un Diálogo espiritual ${ }^{29}$, obra religiosa de un laico; Montemayor, pues, prueba fortuna con el género de los diálogos. Cuando escribe el

29. Vease María Dolores Esteva, "El Diálogo espiritual de Jorge de Montemayor», 1616. Amuario de la Sociedad Española de Literatura General y Comparada, 5 (1983), pp. $31-45$. 
libro de pastores, desaparece la condición religiosa, y tampoco se vale de las resonancias morales que hay en los diálogos de Torquemada, y luego en los de Pedro de Navarra, pero afirma y asegura, en tanto dure la vigencia formal de los libros de pastores, la consideración digna y decorosa de estos personajes, dentro de las normas de humildad que les son propias. La filosofía platónica y los presupuestos de la dignidad virtuosa del cristiano se sitúan en el rasero humano de la variedad de casos de amor, sobre los que opera la ficción en la forma del relato, diferente de la propia del diálogo estricto como género. También ocurre que la vena heraclitiana del cambio como móvil del universo pierde el auge que había tomado, y gana puntos la concepción platónica, pero no deja dé aparecer de vez en cuando, sobre todo aplicada a los estragos de la mudanza femenina. Y la variedad que manifiesta la Diana en cuanto al elenco de personajes recibe su confirmación en la variedad de los interlocutores del diálogo. Esto es lo que permite que los caballeros de ciudad y sus damas acudan al campo en que viven los pastores, como es patente en la Diana de Montemayor. $Y$ esto no se justifica sobre casos reales, pues pudo hacer caballeros enraizados en el campo y aficionados a él, sino porque lo asegura la verosimilitud de las formas literarias, válidas sin más en sí mismas. Por eso en el marco de la naturaleza de la Diana aparece, sin que nadie pueda pedir cuentas, un palacio con jardines y fuentes, en el que los pastores se valen de fragmentos de diálogos filográficos (como son los de León Hebreo) ${ }^{30}$. Y en el curso del artístico entramado de los casos que se reúnen en el libro de pastores, hay ocasión abundante para aprovechar novelescamente los deslizamientos antes referidos: el pastor que razona como filósofo, y el cortesano $u$ hombre de ciudad que se pasa al bando pastoril, lo mismo que ocurre que el pastor pudo haber sido noble o ciudadano. Los libros de pastores, con Montemayor en cabeza y detrás una larga fila en la que figuran Cervantes y Lope de Vega, aprovecharon el ejercicio literario del diálogo establecido en un marco natural, como había ocurrido en las Bucólicas y en la Arcadia; y más allá del mismo, como ya se había insinuado para estas obras, desarrollaron el germen novelístico implicado en las mismas. Y si la otra vîa teatral, también apuntada, apenas logra en España fortuna ${ }^{31}$, sí la obtuvo la vía que iba hacia una afir-

30. Véase Andrés Soria Olmedo, Los «Dialoghi d'Amore» de León Hebreo: aspectos literarios y culturales, (Granada, Universidad, 1984), pp. 93-96.

31. Francisco López Estrada, «La comedia pastoril en España», Origini del dramma pastorale in Europa, (Viterbo, Centro Studi sul Tratro Medioevale e Rinascimentale, 1985), pp. 235-256. 
mación de la gran novela europea ${ }^{32}$. Los españoles reanimaron así la vieja tradición pastoril y la prosiguieron en esta dirección novelesca.

Termino mencionando sólo un nombre que logró sacar un fruto magistral a este cauce pastoril: es el de Cervantes, que supo aprovechar la experiencia literaria del diálogo de forma inmediata en la $\mathrm{Ga}^{-}$ latea y, extrayéndole su esencia novelística, en el Quijote; y no es en vano que el planteamiento más rotundo de la verosimilitud de la literatura pastoril al uso se plantee en el Coloquio de los perros ${ }^{33}$.

Mi conclusión, por los motivos indicados, es que no hubo un aprovechamiento sistemático en nuestra literatura del posible diálogo pastoril en su forma más cabal, como tal diálogo literario; el solo diálogo así titulado y con un desarrollo entre pastores presenta la perturbación que es propia de un deslizamiento de la forma literaria constitucional: junto con la prosa, contiene algunas poesías, más que diálogo es monólogo del protagonista; en la estructura de obra,.Torquemada recurre a paréntesis explicativos como este: "Comienza Torcato a contar el proceso de sus amores con la pastora Belisia» (668.a), impropios de la disposición del diálogo. En suma, apuntan los procedimientos propios de los inminentes libros de pastores, y, a través de ellos, se presumen los procesos de novelización, la nueva forma moderna. Los Coloquios de Torquemada aparecen en una imprenta de Mondoñedo, (1553) en Galicia, relativamente cerca de Astorga y Benavente, en un ámbito local, y sólo se repite su impresión de Bilbao (1584); esto indica que es una obra de escasa difusión. Seis o siete años después de 1553, la Diana de Montemayor inicia su marcha triunfal como un éxito de público, sobre todo femenino, con todas las consecuencias que llegan a Cervantes. Esa es la vía en la que los apuntes, esbozos e intentos de un diálogo entre los pastores, inmaturo como tal, han de triunfar en una nueva unidad de prosa y verso conjuntamente. Por eso lo que aquí he escrito debió haberse titulado: «los pastores conversan», pero no «el diálogo pastoril», al menos

32. Véase Jacqueline Savoye Ferreras, «Del diálogo humanístico a la novela», en el Homenaje a José Antonio Maravall (Madrid, Centro de Investigaciones Sociológicas, 1985), III, pp. 349-358. Sólo se refiere de pasada a Torquemada, y apunta que el diálogo lucianesco utiliza más los recursos de ficción que se integrarían en la madurez de la novela.

33. Véase en relación con los fundamentos medievales, la diferencia entre dialéctica y diálogo, y la profundización del diálogo en el Quijote: Claudio Guillén, "Cervantes y la dialéctica o el diálogo inacabado" [1978], en El primer Siglo de Oro. Estudios sobre géneros y modelos, (Barcelona, Ed. Crítica, 1988), pp. 212-233. 
como tal diálogo renacentista. Cierto que los diálogos contuvieron cuanto la curiosidad del hombre de la época quiso que fuese objeto de examen, y en mínima representación no faltan los pastores para corroborar el sentido abierto que es propio del género, pero poco aportan directamente al grupo de los diálogos. El entremetimiento de los pastores en este grupo resulta posible-como dije-por la variedad de los interlocutores y por el prestigio del macrosistema pastoril.

Pero la experiencia literaria es siempre positiva: cuando los diálogos vayan perdiendo vigencia creadora y pasen de moda, parte de sus piezas y significación proseguirán actuantes en el nuevo grupo literario del libro de pastores y supondrán así un medio de comunicación con otros públicos, en particular el femenino. Y esto permite tender un puente por encima de la erizada cuestión de las consecuencias literarias del Concilio de Trento en cuanto a una serie de cuestiones importantes; como ya indicó Bataillon, lo que algunos críticos han querido que haya sido un cambio radical de la creación literaria, no lo es tanto, y así hay planteamientos procedentes de la primera mitad del siglo XVI que prosiguen su eficacia literaria en la segunda mitad del mismo. Esto hace que el paso de la época del Renacimiento al Barroco, según el signo estético del arte, no sea una frontera, síno una extensa transición que hay que matizar convenientemente para percibir la gran riqueza literaria de los Siglos de Oro. 